\title{
ЗЕН МАЧ: УТИЦАЈ ЗЕН БУДИЗМА НА ЈАПАНСКО МАЧЕВАЛАШТВО
}

Уметност мачевања у Јапану развијала се још од 12. века, а њено усавршавање било је једно од ствари које је највише заокупљивало владајућу класу Јапана. Са̂м период Камакура тесно је повезан са зеном који је, управо тада, први пут уведен у Јапан као независна школа будизма. Велики број ратника окупљао се око бројних зен учитеља а одговарао им је њихов једноставан и непосредан метод подучавања. Наиме, пошто су животи ратника били у сталној опасности, а мачеви једино оружје које је могло да одреди њихову судбину, у Јапану се уметност мачевалаштва развила до чудесног степена савршенства. Зен је умногоме допринео оваквом развоју вештине мачевања у Јапану, а многи мајстори су својим ученицима давали не само савете по питању техника, већ превасходно по питању њиховог менталног става, пре свега по питању њиховог односа према смрти.

Иако је свакако било доста познатих јапанских мачевалаца који су се трудили да рукују мачем по начелима зен будизма, будући ограничени простором, за потребе овог рада смо одлучили да обрадимо и упоредимо дела три мајстора - Мијамото Мусашија, Јагју Муненорија и Такуан Сохоа, који се сматрају најзаслужнијим за сједињење духа зена са духом мача. Надамо се да ћемо анализом њихових дела успети да укажемо на њихову прожетост зен будизмом, чија су основна начела - празнина, не-ум, једноставност, природност - утицали на бројне уметности/вештине у Јапану, а у првом реду и на јапанско мачевалаштво.

Кључне речи: Јапан, мачевалаштво, зен будизам, празнина, не-ум, Мусаши, Муненори, Сохо.

\section{1. УВОД}

Од давнина јапански мач (нихонйо, 日本刀) игра значајну улогу у свести јапанског народа. Наиме, он је једна од три царске релик-

*_liberkokoro@gmail.com 
Соња С. Вишњић Жижовић

вије и један од главних симбола централног божанства шинтоистичког пантеона - богиње Сунца Аматерасу која је свом унуку Нинигију, претку оснивача јапанске царске лозе, предала огледало, драгуљ и мач када је силазио на Земљу.

Историјски гледано, порекло јапанских мачева везује се за VIII век и најранији развој челика у Јапану. Они су задивљујући због раног техничког мајсторства у обликовању челика, као и због елегантног облика, линија, састава и сенки боја у материјалу. За Јапанце, мач већ дванаест векова има духовни значај јер, поред тога што представља једну од три царске реликвије, он симболизује и муњу која се повезује са кишом и пиринчаним усевима. Због тога се у Јапану, још од давнина високо ценило ковање мачева. Најранији ковачи мачева су често били јамабуши или чланови шугендо секте који су са својим шегртима живели аскетским и религиозно повученим животом. По целом Јапану било је отприлике 200 школа јапанских ковача-уметника, а свака је имала своју историју, карактеристике и изненађујуће доследна обележја која се могу пратити кроз више векова уназад. Свака од ових школа имала је и посебан тип каљења оштрице, и управо је хамон ( 刃文), или прекаљени узорак оштрице, један од најлепших и најособенијих делова мача, али и важно средство за утврђивање његовог порекла.

Стручњаци тврде како се нигде у свету не праве ни приближно тако добре оштрице као у Јапану, а оно што разликује јапанске оштрице од других јесте њихов састав. Наиме, Јапан се са технологијом гвожђа упознао између III и IV века, а већ од VIII до X века у Јапану су се правиле оштрице високог квалитета. Након што би се челик исковао, површински слој гвожђа или оплата (каваїане, 皮金) ковала се, 10 до 20 пута, у плоче које су се онда очвршћавале, разбијале у делове величине новчића, развијале и поново спајале. После се овај очвршћени челик припајао уз површину мање кртог унутрашњег челика (иинїане, 心金). Ово понављање пресавијања и спајања, дало је јапанској оштрици један од њених јединствених квалитета, а то је састав попут влакни дрвета - Ђuxaga (地肌).

И поред значајног историјског развоја јапанске оштрице, ми смо се одлучили да укажемо и на „духовне“ вредности јапанског мача. Наиме, према речима једног од великих познавалаца Јапана, Ричарда Сторија (Richard Storry), култ мача у јапанској историји и фолклору 
заузима значајно место: „Као оштрица за сечење, као уметничко дело, као талисман и фетиш, мач самураја уживао је јединствено поштовање. Јапански ратници сматрали су да мач живи свој живот, а они поражени у борби одлазили су у храмове да се моле богу рата Хаћиману $^{1}$ и питају га зашто је њихов мач изгубио дух. Тако се веровало да мач у рукама грубог и агресивног човека може да постане оружје којим се дивља, али да у рукама мајстора који негује буши но насаке, или ратничко осећање милосрђа и благости, може да постане доброћудан и да чак очува живот““ (Стори 1987: 50).

Важно је напоменути како јапански мач мора да одражава нешто што снажно делује на дух људи. И заиста, Јапанци на њега не гледају као на оружје којим се уништава, већ на предмет надахнућа. Отуда и легенда о ковачу мачева Оказуки Масамунеу:

Крајем периода Камакура (1185-1333), у благостању је живео велики ковач мачева Масамуне, а његове творевине подједнако су ценили сви познаваоци мачева. Што се тиче ивице оштрице, Масамуне можда не превазилази Мурамасу, једног од његових најспособнијих ученика, али за Масамунеа се причало да има нешто што морално надахњује а потиче из његове личности. А легенда гласи овако: Jegном је јеgан човек, желећи gа ирровери нарав Мурамасиної мача, сйавио

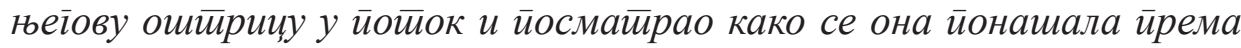
увелом лишћу које је мирно йловило йо йовриини воgе. Међуйим, сва-

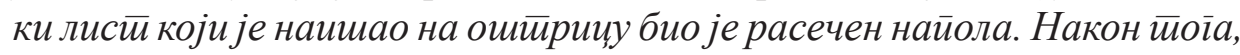
човек је у воgу сйавио Масамунеов мач и са изненађенем иримейио како је лишће лаїано заобилазило ошитрииу и остиајало нейакнуйо. Причало се gа је йо йоказивало Масамунеов каракӣер који је имао оg-

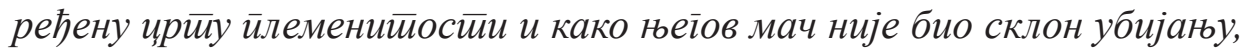
gок Мурамасин мач није ӣревазишао сечење и у њему није било ничеїа

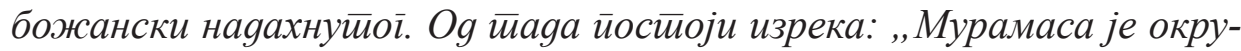
шан, а Масамуне је хуман. “ Другим речима, карактер човека који је направио оштрицу везивао се за сам мач (Сузуки, 2005: 79).

1 Највећи број шинтоистичких храмова посвећен је божанству Хаћиман који се повезује са рудницима бакра и кланом Минамото. Када је за изградњу будистичких храмова била потребна велика количина драгоцених метала, царски емисари одлазили су у храмове и молили се Хаћиману да открију додатну количину злата. Двор се обраћао Хаћиману и с молбом за заштиту од епидемија и смиривање друштвених немира. Касније је Хаћиман преузео улогу божанства рата и молитве које су му упућиване тицале су се заштите Јапана током ратова. 
Соња С. Вишњић Жижовић

Тако су се 'духовне' вредности мача уклапале у савршенство његове уметничке израде. „Мало повијен, између равне оштрице европског витеза и српастог облика сараценске криве сабље, одавао је јединствено савршенство самурајског оружја“ (Стори 1987: 50). На површини су се налазиле неправилне шаре велике уметничке лепоте, такозване „фигуре оштрице“, које су представљале морске таласе или врхове планина, начињене од различитих материјала при процесу каљења и ковања, што је сигурно утицало на то да су јапански мачеви били познати у свету пре јапанског дрвореза у боји, но драме или хаику поезије. Разлог за ово је можда у односу Јапанаца према мачу који за њих не представља само ратничку опрему, већ и, под утицајем философије зен будизма, уметничко дело и Пут којим се одстрањује властито незнање и его.

\section{2. ЗЕН БУДИЗАМ У ЈАПАНУ}

Будизам је као учење дошло у Јапан средином VI века, али је свој пуни развој достигло тек у XII веку. Доневши са собом не само индијску философску мисао и будистичку метафизику, већ и традиције кинеске цивилизације (јер је у Јапан пренето из Кине, а преко Коpeje, 552. године када је краљ корејске државе Паекче послао мисију јапанском цару која је носила поклоне укључујући и Шакјамунијев лик у злату и бакру и велики број сутри), учење Буде допринело је „фомирању административно-бирократске хијерархије у Јапану и неких принципијелних основа система етике и права. Будистичке норме су у Јапану биле изузетно јаке и одиграле су битну улогу у постављању темеља јапанске културе" (Василијев 1987:282-283). У прилог томе говори и чињеница да су у XVI веку, у доба политичких немира и сталних борби, јапански зен учитељи били ти који су сачували културни живот земље, развијајући и усавршавајући уметност, књижевност, чајну церемонију, но позориште.

Тако је за разумевање јапанског зен будизма важна чињеница да су Јапанци ово учење примили из Кине, где је било познато као чан, који је, пак, био резултат асимилиације кинеске философске мисли и индијског будизма: „Прагматичка страна кинеског менталитета је на утицај индијског будизма реаговала тако што се усредсредила на 
његове практичне аспекте и развила их у једну посебну врсту духовне дисциплине којој је наденуто име чан, што се обично преводи као медитација" (Капра 1989:139). Управо је ову философију чана Јапан прихватио у XII веку, која се под именом зен негује и данас.

Зен учи да се буда-природа, или потенцијал за достизање пробуђења, налази у сваком човеку али да је успавана због незнања. Најбоље ју је пробудити не проучавањем светих текстова, извршавањем обреда и церемонија, или обожавањем ликова, већ изненадним пробијањем граница општеприхваћене, свакодневне, логичке мисли. До пробуђења (јап. сайори 悟り) може се доћи упорним тренингом који се најбоље може пренети са учитеља на ученика. Међутим, методе достизања пробуђења разликују се од школе до школе. Тако школа ринзаи (кински: Лин чи), коју је у Јапан донео јапански свештеник Еисаи (栄 西) 1191. године, наглашава изненадни шок и медитирање на прадоксалним изјавама (јап. коан). Школа сото (кинески: Тсао-тунг), коју је у Јапан донео Доген (道元) на свом повратку из Кине 1227. године, преферира метод седења у медитацији (јап. зазен, 座禅). Трећу школу, обаку (кинески: Хуанг-по), основао је кинески монах Јин-јуан (на јапанском Инген, 隠元), 1654. године. Ова школа је усвојила методе школе ринзаи, али практикује и нембуиу (зазивање имена Буде Амиде).

Ипак, од свих јапанских будистичких школа и учења, зен будизам је највише прожео живот Јапанаца и њихову културу и уметност. Као што смо већ навели, назив „зен“ потиче од санскртске речи gхуана, или „медитација”. Верује се да је она један од начина доласка до потпуне свесности крајње/врховне стварности, и била је значајна пракса како у Индији, тако и у Кини и у Јапану. Медитација се сматра вежбањем менталне концентрације која води кроз нивое до коначног циља духовног ослобођења, или нирване. Према речима Чогјам Трунгпе (Chogyam Trungpa), „иако постоје два значења медитације (први се заснива на традицији која се бави проучавањем природе ствари, а друга се састоји у успостављању везе са спољашњим или универзалним концептом Бога), у оба случаја она представља једини пут којим се теорија претвара у праксу“ (Трунгпа, 2003: 26). Директна спознаја је процес у коме објекат нашег сазнања и ми сами (као субјекат) постајемо једно, а то се постиже кроз медитацију. Према томе, медитација је ствар праксе, радна навика. Она није само понирање у унутрашњост, већ и ширење ка спољашњости. 
Тако је циљ зен будизма да са̂м човек досегне дубоку спознају јединствености свега, када превазилази стање ума које пореди, разликује и верује у илузију подвојености. Овај концепт јединства прожима све око нас. „У зен будизму лепота се налази у једноставности и смирености, у осећању свеобухватне хармоније ствари. То је лепота која одражава мир и празнину, које увек обитују усред сталних промена. Човек зена лепоту налази у једноставним стварима: у стенама и води, у маховини, биљкама, песку, рибњацима и малим дрвеним мостовима" (Разић 1985: 53). Пошто се лепота свега око нас може осетити сједињавањем са објектом наше пажње, погрешно је мишљење да је зен будизам повлачење из свакодневног живота. Пут зена није одбацивање свакодневних послова како бисмо могли да увежбавамо медитацију. Иако смо сами док је вежбамо, то не значи да смо изоловани и одвојени од свега што нас окружује. Иако смо физички сами, потребно је духовно сједињење са свиме око нас, јер медитација није чин личног ега, већ пробијање његових граница и сједињење са свиме. Према речима Дејана Разића, медитација чак и не мора да се упражњава у самоћи, већ можемо да је примењујемо и достигнемо пробуђење у свакодневном животу, у обичном послу, у контакту са људима, у настојању да их разумемо, јер се у свему налази Истина, или стварност. Тако је основни циљ будизма, као и зен будизма, достизање пробуђења ${ }^{2}$ (ибиg 1985: 53). Јапанска реч за пробуђење је сайори, а изведена од глагола сайору (悟る), што значи „освестити се“, „пробудити се“. Сатори би се могао дефинисати као интуитивно сагледавање ствари, насупрот аналитичком или логичком разумевању. Тада све супротности и противречности постају уједињене и хармонизоване у органску целину. Сайори се односи на целокупност живота. Када је Бодхидарма дошао у Кину почетком VI века, покушао је да унесе елемент саторија у будизам који је тада био обузет финесама философских расправа. Међутим, искуство просветљења мора се доживети личним напором. Учитељ може да укаже на пут, али крајњи скок остаје на ученику. Пробуђење је буђење или освешћивање у самом себи и не зависи ни од кога другог. Оно оспособљава човека да сагледа свет у вечној хармонији и лепоти јер је она заправо „повратак Извору или враћање кући“. Оно је први корак ка

2 Међутим, ово није случај у религијском будизму (ђодо) где је основни циљ рођење у рају по милости Буде Амиде. 
ЗЕН МАЧ: УТИЦАЈ ЗЕН БУДИЗМА НА ЈАПАНСКО МАЧЕВАЛАШТВО

потпуној слободи. Тако се пракса зен будизма заснива на личним напорима појединца да истраје у борби против своје ниже природе која се темељи на жудњи за животом и поседовањем ствари, што везује човека за Точак рађања и умирања. Када се спозна властита природа, сагледава се поредак ствари и прихватају се ствари онаквим какве оне и јесу. Тиме је човеков живот у хармонији и срећи које се достижу на сваком месту.

Будући да зен будизам првенствено истиче лично искуство и спровођење теорије у праксу, лако је могао да пронађе свој израз и у мачевалаштву као борбеној вештини која је захтевала одлучно реаговање и акцију.

\section{3. ЗЕН И ЈАПАНСКО МАЧЕВАЛАШТВО}

Уметност мачевања развијала се још од периода Камакура (11851333), а њено усавршавање било је једно од ствари које је највише заокупљивало владајућу класу Јапана. Са̂м период Камакура тесно је повезан са зеном који је управо тада, први пут уведен у Јапан као независна школа будизма. Бројни зен-учитељи управљали су духовним животом тог периода, а око њих се окупљао велики број ратника којима је одговарао њихов једноставан и непосредан метод подучавања. Заправо, ратницима тог периода живот је стално био угрожен, а учење зена им је нудило неко решење тог проблема, док су зенучитељи радије прибегавали животним чињеницама, него појмовима. Такође, „зен је религија снаге воље, а снага воље је оно што је преко потребно ратницима, мада она мора бити просветљена унутарњом спознајом“ (Сузуки, 2005: 58).

Пошто су животи ратника били у сталној опасности, а мачеви једино оружје које је њихову судбину могло приклонити животу или смрти, уметност мачевалаштва развила се до чудесног степена савршенства. Зен је умногоме допринео оваквом развоју вештине мачевања у Јапану, а многи мајстори су својим ученицима давали не само савете по питању техника, већ превасходно по питању њиховог менталног става.

Спремност јапанског ратника да одлучно реагује и иде напред (да неустрашиво гледа смрти у очи) није требало да представља слепу неустрашивост, већ напуштање свога $j a$, у будизму познато као стање 
Соња С. Вишњић Жижовић

ослобођености од ега. Управо на овом месту почиње религиозни смисао уметности мачевања. На овај начин, зен је дубоко продро у разне видове живота Јапанаца: морални, практични, естетски, па у извесној мери и интелектуални.

Зен велику важност придаје интуицији, док негира и одбацује вежбу рационалног и вербалног интелекта. Због тога је погодовао свести ратника која се не руководи метафизичким спекулацијама или философским расправама, већ, попут зена, показује своју снагу у акцији. Зен равнодушно гледа на живот и смрт - ни о једном ни о другом ни за тренутак не треба размишљати. Најбитније је да човек даје све од себе без обзира на рационалне или ирационалне закључке до којих је дошао. Тако зен пропагира инстинктивну и непомућену вољу која постоји овgе и саga.

На овај начин је утицај зена на самураје био пресудан. Он је донео сасвим ново гледање на употребу лука и мача који, уколико се нађу у рукама мајстора, могу да достигну савршенство. Међутим, постојао је још један, можда најзначајнији чинилац који је посебно допринео да зен буде прихватљив за оне чији је живот већ дубоко био прожет древном јапанском религијом, шинтоизмом. Главни обред у шинтоизму је хараи или „(про)чишћење“. Најобичнији симбол овог обреда је посетилац који испира уста и пере руке у посуди с водом пре уласка у унутрашњост светилишта. Свака врста „чишћења“, од најједноставнијег до најузвишенијег, осмишљена је да у јапанском ратнику створи, или тачније, да поново створи ,јасно и чисто срце“, док је оружје које је носио за појасом било симбол онога што носи на уму и срцу - оданости и части (апуд. Стори, 1987: 48).

Стога је битан део упражњавања зена био усмерен на ослобађање човековог „правог карактера“ (хоншо, 本性). Ово није био толико процес изградње колико „скидања“ и одбацивања свих спољашњих елемената све док се не постигне стање $м y$ (無), односно стање празнине, чистоте, непостојања - стање испражњености од сопства и сувишног садржаја (мисли и предрасуда).

Када је реч о самурајима, шинтоизам им је обезбедио традицију, конфуцијанизам дао етички кодекс, а зен формирао њихово понашање у миру и рату. Израда и руковање ратничким мачем тачно илуструју снагу овог тројства (апуд. Стори 1987: 49). Израда сечива био је свечан и религиозан поступак. Ковач мачева није био само занатлија, 
већ надахнути уметник, а његова радионица светилиште. Од почетка до краја, процес ковања мача текао је по законима шинтоизма. Оног тренутка када би дошао у руке самураја, циљ мача био је да настави службу коју дугује свом законитом господару. Тако је конфуцијански етички кодекс подржавао обавезу оданости господару. Међутим, када се једном извуче из корица, њиме треба руковати у духу зена, сигурног и најачег вође у његовој делотворној употреби.

„...Да ли је то дух мајстора или његовог бога заштитника бацио чини на наш мач? Савршен као уметничко дело, односио се са презиром према својим ривалима из Толеда и Дамаска и био више од онога што уметност може да пружи. Његово хладно сечиво, које је на својој површини чувало тренутак кад је удахнуло пару из ваздуха; његова беспрекорна текстура која блиста светлом плавичастог сјаја; његова неупоредива оштрица на којој читамо историју и њене могућности; кривина његовог сечива која сједињује изузетну елеганцију са крајњом снагом - све ово нас прожима помешаним осећањима моћи и лепоте, страхопоштовања и ужаса. Безазлена би била његова мисија да је остао само предмет лепоте и радости! Али увек надохват руке, представљао је велико искушење. Исувише често је севнула оштрица из његових мирних корица. Злоупотреба је ишла толико далеко да је челик испобаван на врату неке невине особе. Ипак, одговор на питање да ли је бушидо оправдавао употребу оружја је недвосмислено, не!“" (Нитобе 1986: 90-91).

Ово потврђује изјава једног од највећих јапанских мачевалаца, Цухаре Бокудена (塚原卜伝, 1490-1572) који каже да је мач превасходно ту за уништавање себичних побуда, а не да би убијао друге. И велики мачевалац из XVII века, Јагју Муненори (柳生宗矩, 1571-1646) залагао се за животодавни мач, па своју књигу Хеихокаgеншо завршава овим речима: „...Мач који убија људе може, напротив, постати мач који им даје живот. У хаотичном друштву, многи су убијени без разлога. Смртоносни мач се користи да се хаотично друштво стави под контролу; али, када се то једном учини, не може ли тај исти мач постати животодаван?“ (Муненори, 2006: 91) Зен управо говори о мачу живота и мачу смрти и потребно је знање великог зен-учитеља да би се проценило када и како треба употребити један или други. Мањђушри ${ }^{3}$ држи мач данас у десној, а сутра у левој руци, али његов

3 Мањђушри; један од двојице најважнијих бодхисатви у систему веровања 
Соња С. Вишњић Жижовић

свети мач није ту да убије било које свесно биће, већ нашу похлепу, љутњу и незнање. Тако се сматрало да се манифестација зена могла најбоље уочити, пре свега, у мачевању. Два мача, дугачки и кратки, који су висили о појасу са оштром ивицом нагоре, представљали су највеће благо самураја - његов статус и симбол части. Зен је могао до савршенства да доведе употребу лука, копља, хелебарде, мускете и глатке цеви, али је само мач остао оно што се назива „душом самураја“" (Стори, 1987: 49). Па ипак, када Јапанци кажу да је мач душа самураја, треба истаћи и особине које иду уз њега: оданост, пожртвованост, поштовање, доброћудност и неговање других узвишених осећања. Све ово чинило је истинског самураја. Према томе, мач мора да буде оружје којим се убија его - корен свих сукоба. Да би се ово постигло, потребна је искреност према самоме себи која човека води до откривања Небеског Пута који је изнад сопства, а то је мушин (無 心), „не-ум“ или мунен (無念), „не-мисао“. Када се достигне мушин, ум не познаје сметње ни инхибиције и ослобађа се мисли о животу и смрти, добитку и губитку, победи и поразу. Човек који је у потпуности овладао овом уметношћу, не употребљава мач, а када га користи онда тај мач другоме даје живот.

\section{4. ЈАПАНСКИ МАЈСТОРИ МАЧА}

Вежбати хиљаду дана је дисциплина, а вежбати десет хиљада дана је дотеривање. Мијамойо Мусаши

Као што Даусецу Сузики наводи у свом делу Зен и мачевалаш$\bar{u} в о$, с одређене тачке гледишта Јапан XVI века изнедрио је велики број изванредних људи. Земља је такорећи била расцепкана и у политичком и друштвеном смислу. Широм Јапана феудални господари међусобно су ратовали. Народ је сигурно много патио, али то смртоносно такмичење за војну и политичку надмоћ између ратничких класа помогло је да се до крајности, на сваки могући начин, напну духовне и моралне снаге. Крепкост се потврдила у различитим сфера-

махајанског будизма. Он је оличење йрађне, или мудрости. Будистичка иконографија га приказује са мачем знања у рукама и књигом која симболизује његову мудрост 
ма живота (апуд. Сузуки, 2005: 69). Можемо рећи да се већина врлина које сачињавају кодекс самураја (бушияо) формирала у овом периоду.

Само стотину година касније, у раном периоду Едо (1603-1868), у времену интензивног развоја борилачких вештина, појавиће се три приручника која ће се испоставити као изузетно утицајна за прожимање мачевалаштва духом зена. Једно је дело зен свештеника и мајстора чаја, Такуан Сохоа (沢庵宗彭), Мистиериозни зайис нейокрейне мудростии (Фудоћи шинмјороку, 不動智神妙録), написано око 1632. године. Ово дело је у основи философски текст који углавном потцртава потребу да се ум ослободи сваке везаности и фиксације. Друго дело

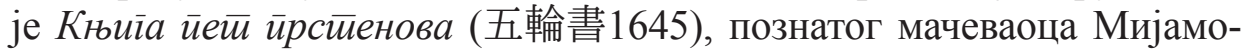
то Мусашија, несвакидашњег човека који се није везивао ни за једно учење, ни школу. Године 1632. Јагју Муненори је написао књигу Хеихо

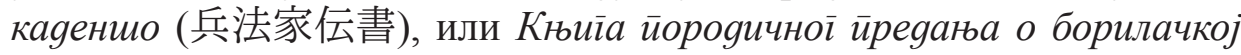
вешимини и војној стирайеїији. Философски и психолошки аспект је у великој мери преузет из Такуановог писма-дела Мисиериозни зайис нейокрейне мудростии. Што се тиче самих техника и вежбе, Муненори је наследио дугу линију својих претходника, а верује се да је ове технике, укључујући и чувену технику не-мача, довео до савршенства.

Иако је свакако било доста познатих јапанских мачевалаца који су се трудили да рукују мачем по начелима зен будизма, за потребе овог рада, и због ограниченост простора, одлучили смо се да обрадимо и упоредимо дела споменута три мајстора, који се сматрају најзаслужнијим за сједињење духа зена и мача. Иако један од њих (тј. Такуан Сохо) није био мачевалац, али је свакако био упознат са начелима мачевалаштва и био је врста духовног учитеља двојици најпознатијих јапанских мачевалаца - Мијамото Мусашију и Јагју Муненорију.

Надамо се да ћемо анализом споменутих дела успети да укажемо на њихову прожетост зен будизмом, чија су основна начала - празнина, не-ум, једноставност, природност - утицали на бројне уметности/вештине у Јапану, а у првом реду и на јапанско мачевалаштво.

\section{1 Мијамото Мусаши}

Мијамото Мусаши (1584-1645) рођен је у селу Мијамото, у провинцији Мимасака, у Јапану. Овај велики мачевалац, чија ће вештина тек након његове смрти постати легендарна, живео је у периоду у коме је Јапан покушавао да се опорави од четири века унутрашњих 
борби и разарања. Традиционална царска власт је била збачена још у XII веку и иако је сваки цар остајао као главна фигура власти, његове надлежности и моћи биле су у великој мери смањене. Од тог времена, Јапан је био у готово непрекидним грађанским ратовима између локалних земљопоседника (gаимјоа или феудалних господара), монахаратника и аристократије, који су се међусобно борили за земљу и моћ. У XV и XVI веку, феудални господари су, првобитно у циљу заштите, градили велике замкове-утврђења који ће касније постати економски и трговачки центри.

Међутим, 1573. године, на чело државе долази Ода Нобунага. Он је за само девет година успео да преузме контролу над целом земљом. Када је 1582. године убијен, на чело државе долази човек из трећег сталежа под именом Тојотоми Хидејоши. Он је наставио рад на уједињењу Јапана који је отпочео Ода Нобунага, немилосрдно уклањајући сваки могући траг побуне. Хидејоши је својом забраном ношења оружја поново оживео стари јаз између ратничке класе (самураја) и људи из трећег сталежа. Наиме, његов познати „Лов на мачеве“ (1588) значио је да једино самураји могу да носе оружје, тачније, дугачки и кратки мач који их је разликовао од остатка популације.

Иако је Хидејоши учинио много за стабилизовање Јапана и увећање трговине са иностранством, у време његове смрти (1598), у Јапану је још увек било доста немира и сукоба. Стварна изолација и уједињење Јапана отпочели су са инаугурацијом велике владавине Токугава. Године 1603, Токугава Иејасу, претхоно помоћник и Оде Нобунаге и Тојотоми Хидејошија, званично је постао шогун након победе над Хидејошијевим сином Хидејоријем у бици Секигахара (1600). Иејасу је своју престоницу основао у Еду (данашњи Токио) где је подигао огроман замак. За време периода Токугава, власти ће спровести стабилну и мирну владавину која ће трајати све до Меиђи обнове 1868. године. Период Токугава бележи велике промене у друштвеној историји Јапана. Токугава бирократе имале су сву власт. Нису се само контролисали образовање, закон и влада, већ и понашање и обичаји људи. Друштво је било ригидно подељено на четири класе (ши-но-ко-шо): самураје, сељаке, занатлије и трговце, а највиши рангом били су самураји или ратници.

Мијамото Мусаши припадао је управо самурајској класи друштва. Његово пуно име је било Шинмен Мусаши но Ками Фуђи- 
вара но Геншин. „Мусаши“ је назив подручја југозападно од Токија, а „но ками“ означава особу племенитог порекла, док је назив „Фуђивара“ име племићке породице која је владала Јапаном преко хиљаду година. Иако је био племенитог порекла, Мусашијев живот је био изузетно тежак, а са̂м Мусаши несхваћен у своје време. Када је напунио седам година, отац му је или умро или га напустио. Пошто му је и мајка умрла неколико година пре тога, Мусаши је неко време живео са ујаком свештеником и његовом женом, да би касније живео као ронин, тј. лутајући ратник или самурај без господара. Мусаши је за Јапанца тог времена био изузетно крупан и висок (175 цм) и вероватно му је отац усадио љубав према мачевању. Записано је да је са само 13 година имао први дуел из кога је изашао као победник, а у 16. одлучује да напусти дом и лута Јапаном. У свом „ратничком ходочашћу“ Мусаши живи изван друштва и посвећује се само једној идеји - (само) остварењу на путу мача. Тада, не чешћљајући косу, ретко се купајући, одричући се жена, нити се опредељујући за неко одређено занимање, само се посвећује својој потрази. Око 30. године одлучује да више не учествује у двобојима, а до тада је учествовао у њих преко шездесет (из сваког је изашао као победник) и неколико великих битки (између осталог и у чувеној битки Секигахара, 1600. године). Након битке Секигахара на власт уместо Тојотоми Хидејошија долази Токугава Иејасу, а Мусаши, који се борио на пораженој страни, одлази у престоницу, Кјото. Тада је са собом већ носио дрвени мач који је у двобојима користио уместо правог.

Године 1605. одлази на југ престонице, у храм Хозоин, где је учио технике борбе копљем и уживао у разговору са монасима.

Настављајући да лута земљом, борио се у провинцијама Ига, Изумо, али и у Еду (данашњи Токио). Након што одлучује да више не учествује у двобојима, прикључио се Токугава војсци (против које се 1600. године борио у бици Секигахара). Према његовим записима, (војну) стратегију је тек почео да схвата у 50. или 51. години живота (1634).

Са усвојеним сином Иоријем, дечаком кога је срео на својим лутањима, одлази у место Огура, на острву Кјушу које више неће напуштати. Након шест година проведених у месту Огура, господар Хосокава позива Мусашија као госта у замак Кумамото. Са господаром Ћуријем остаје неколико година, а време углавном проводи у 
Соња С. Вишњић Жижовић

сликању. Године 1643. повлачи се у осаму. Само неколико недеља пре него што ће умрети, у мају 1645 . године, пише своје чувено дело Го рин но шо, или Къиїа иеей ирстенова.

Када би га питали где је научио да се бори, Мусаши је говорио да је прве лекције добио од оца који је вероватно био добар борац, али да је, када је остао сам, често одлазио у шуму, тамо проводио дане, недеље и месеце учећи од ветра, воде, животиња и птица.

Мусашијеве ударце нико није могао да предвиди јер су се разликовали од потеза који су се учили у тадашњим школама борења, а многе покрете никада није понављао јер је, како је тврдио, своје потезе прилагођавао противнику. Мусаши је често говорио да учи од својих противника у двобоју и да је учење једини разлог због кога се бори.

Мусаши је имао и другачији однос према смрти од осталих самураја његовог доба. Док су многи јапански ратници, према кодексу самураја, и најмању увреду сматрали поводом да изврше самоубиство, Мусаши је био уверен да је овај чин одраз кукавичлука. Сматрао је да је главни задатак сваког човека да у животу искористи све могућности које стоје пред њим како би се усавршио у ономе што ради и тиме дао допринос универзуму. Мусашијева идеја да је сваки човек део универзума и да га унапређује ако себе усаврши, доста је утицала и на његово поимање пута мача (кенgо). Себи је као главни задатак поставио усавршавање мачевања и, како он то каже, „ишао је путем мача“" целог свог живота. Тако је временом основао властиту вештину Хеихо која се није толико заснивала на самим техникама, већ на властитом усавршавању кроз искреност и поштовање природе и свих живих бића. Наиме, Мусаши је веровао да постоји суштина свега онога што је у природи и да када се овлада суштином, човек може да однесе победу у свакој борби, да успе у сваком подухвату. Зато је и заступао мишљење да се ментални став ратника ни по чему не разликује од менталног става обичних људи и да свако треба да се труди да до Истине дође широко отвореног срца.

Овакав приступ вештини мачевања доста се разликовао од приступа осталих самураја тог доба и Мусаши је у своје време био несхваћен и одбачен (ни један феудални господар није хтео да га прими у своју службу јер су остали самураји били против њега).

С обзиром на мишљење да добар мачевалац не поседује само технику, о Мусашију нам доста говори његов надимак кенсеи или 
„светац мача“. Његова Кюиїа йей йрстиенова сматра се једном од најбољих књига о борилачким вештинама и мачевању уопште. Мусаши је писао да када се једном овлада Путем све постаје јасно и Пут се види у свему. Мусаши је рекао да треба учити путеве свих занимања и очигледно је да се и са̂м придржавао овог правила: лутао је у потрази не само за великим мачеваоцима, већ и свештеницима (као што је његов пријатељ Такуан Сохо), тактичарима, уметницима, занатлијама, а све у жељи да прошири своје знање. Тако је Мусаши, поред тога што је један од највећих јапанских мачевалаца, познат и као врсан сликар, песник, скулптор, као неко ко је био упознат са путем чаја, но драмом и, вероватно, столарством. Неке од његових слика и калиграфија сматрају се ремек-делима јапанског сликарства. Сликајући животиње, природу, змајеве, храмове и цвеће, Мусаши је успео да своје идеје пренесе и на платно. Правио је и скулптуре у металу и дрвету. Слике је некада потписивао печатом „Мусаши“ или псеудонимом „Нитен“ (Два неба) за који неки сматрају да се односи на његов борбени став са два мача високо подигнута изнад главе. Основао је школу познату као Нитен-рју која се негде назива и Енмеи-рју (Чист круг).

Ипак, поред описа бројних техника, разних стилова и школа, истицања упорности, марљивог вежбања, као и одлучности на путу

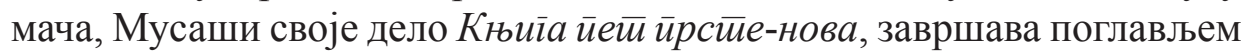
Празнине, у коме каже:

„Нека вам је искреност темељ, водите се исправним умом, широко сагледајте борилачку вештину, имајте јасно и исправно разумевање (ствари) и размишљајте свеобухватно. Сходно томе, празнину ћете начинити путем, и видети пут као празнину“ (Мусаши 2006: 104).

Тако утицај зен будизма на Мусашијево схватање пута мача видимо управо у његовој употреби једног од основних појмова и начела зена, а реч је о празнини. Она је важан концепт првенствено у таоистичкој философији која је и утицала на махајана будизам у Кини и допринела формињању кинеске чан школе будизма, која ће и бити пренета у Јапан и постати позната као зен. Таоистички философи и зен учитељи сматрали су празнину једино свеобухватном и да се Пут (тао) сажима у празнини. Празнина као предуслов за разумевање таоа означава стање постпуне ослобођености од субјективности, а то је значило заборав (губитак) себе (сопства) - испражњеност практиканта/вежбача/уметника/ствараоца од сваког емоционалног и интелекту- 
Соња С. Вишњић Жижовић

алног терета, мисли, правила. Тако је, рецимо, према Херигеловим речима, „медитант испражњен од свега, па ипак не и свестан испражњености. То је стање у које може ући само особа са дугом праксом медитације. Гледано споља, медитант изгледа као да је мртав. Виђено изнутра, он је у стању апсолутне слободе (празнине), испуњен и потпуно жив, напет, усредсређен, па ипак без намере да опсути напетост у форми слика, већ радије да буде напињан, лишен слика, у несликовном пољу моћи“ (Херигел 2005: 83).

У борилачакој вештини (рецимо, мачевалаштву) борац управо дела из ове празнине која му омогућава да се слободно и лако прилагођава противнику. О томе је писао и Мусашијев савременик, чувени мачевалац Јагју Муненори.

\section{2 Јагју Муненори}

Јагју Муненори (1571-1646) је био јапански мачевалац који је, од свог оца Јагју Секишиу Мунејошија, наследио школу мачевања стила Јагју Шинкаге. Стил Шинкаге је био један од два званична стила који је подржавао Токугава шогунат (други стил је био Итто рју). Муненори је рођен у селу Јагју, у околини Наре, а у близини некадашње престонице Кјото. Имао је четворо старије браће и шест сестара. Отац га је од малена подучавао мачевалаштву, војној и политичкој тактици да би га припремио за могућу одговорност вођства све моћнијег и утицајнијег Јагју клана.

Захваљујући пријатељству са зен свештеником, песником и мајстором чаја, Такуан Сохоом, Муненори се данас сматра особом која је заслужна за спајање зена са уметношћу мачевања. Захваљујући Такуановим писмима (Мистиериозни зайис нейокрейне мудростии, Чисти звук gраїуља и Анали мача Таије) Муненори је могао да стекне дубљи и јаснији увид у то да су проблеми са којима се суочава мачевалац заправо одраз човекове унутарње борбе на његовом путу самоостварења. У друштвеним односима примењивао је философију конфуцијанизма коју је учио од оца. Иако је био у служби Токугава шогуна, Муненори није волео рат, већ се залагао за мир. Умро је 1646. године, седећи у медитативном положају.

Јагју Муненори је стекао статус легенде. Многе приче су везане за његове изванредне способности, а међу њима је најпознатија она о задивљујућем осећају за приближавајућу опасност: Док је јеgном ме- 


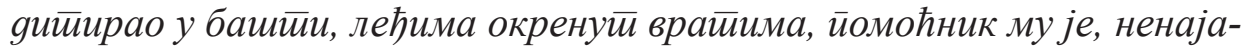
вљен и ииихо, gонео мач. Млаяић тиаg иоомисли gа би било занимливо вияетии како би њеі̄ов учииеељ реаїовао каgа би їа найао. У йрену, Муненори је скочио на ноїе, окренуо се и изненађено уіллеgао само слуіу на врайима. Био је убеђен gа се ириближавала нека ойасности. Касније ì је овај gоїађај gостиа мучио. Како је моїао оg йомоћника gа йомисли

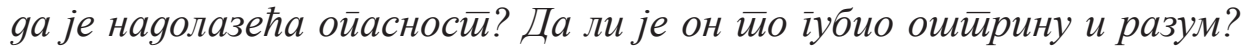
О gоїађају је јеgном ириликом иричао са својим савейницима. Међу юима је био и млаgић-слуїа који је ирризнао gа је йомислио gа найаgне їосйоgара, али йо није учинио. Таgа је Муненори схвайио gа није

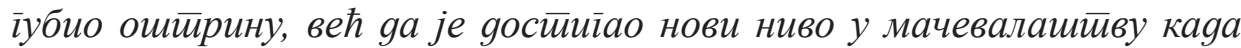
може gа йреgосейи найаgачеву намеру. (Муненори 2006: 8, 9).

Муненоријево дело Хеихо каgеншо је кратак преглед већ научених техника, детаљних упутстава за даље вежбање, медитативни извор за одбацивање психолошких препрека које у себи има вежбач, и философска основа за коришћење мача радије као оруђа које даје живот, него смрт. Тако Муненори у својој књизи каже:

„И једна мисао је болест. Мислити само на победу је болест. Мислити само о употреби борилачке вештине је болест. Мислити о демонстрацији нечијег тренинга је болест, као што је и болест само мислити о нападу или чекати да вас нападну. Мислити на одређени начин само да би се потиснула болест је, такође, болест. Све што се задржава у уму може се сматрати болешћу. Пошто су у уму присутне разне болести, морате ум довести у ред тако што ћете га ослободити свих болести.

[...] Избацити све болести из ума, пробудити обични ум, а опет боравити усред болести - ово је стање када сте без болести. [...] Срце човека Пута је попут огледала: ништа не чини и савршено је чисто. Због тога, он има не-ум и нема ствари којој нешто недостаје. Ово је обични ум. Човек који све чини и постиже са овим обичним умом назива се учитељем.

[...] Када уз непрекидни напор акумулирате дисциплину (а да тога и нисте свесни), оставићете по страни мисли да ли нешто радите како треба и достићи ћете царство не-ума/не-мисли, и оно ће се испољавати у свему што радите, а да о томе и не размишљате. Ваши покрети биће попут механизма дрвене лутке. Тада нећете бити свесни самих себе а ум вам неће бити окупиран ониме што радите. Због тога, 
Соња С. Вишњић Жижовић

десет од десет пута, ваше тело, руке и ноге неће погрешити. Али, ако вам ум склизне барем мало, промашићете циљ. Када имате не-ум, мету ћете погодити сваки пут.

Међутим, не-ум није стање када уопште нема ума. То је једноставно стање обичноі ума“" (Муненори 2006: 43, 46-47).

Овај не-ум заправо је обични ум и борави у Празнини. Заправо, Муненори истиче како ум нема облик, ни боју, да је он Празнина (апуд. Муненори 2006: 69). Он чак истиче како будизам учи да је ум (обични ум) празнина, али да је мало људи достигло спознају иако много њих говори о празнини. Он каже: „Када се ум не креће он је празнина. Када се празнина креће она је ум. Када се празнина креће, она постаје ум и тада у акцију ступају руке и ноге“ (Муненори 2006: 70). Тако он закључује да иако се ум не може видети, када се покрене чини разне ствари: са стопалима корача, са рукама обухвата а са духом чини чуда (апуд. Муненори 2006: 71).

\section{3 Такуан Сохо}

Такуан Сохо (1573-1645) је био зен монах, калиграф, сликар, песник, баштован и мајстор чајне церемоније. Био је саветник и учитељ људима из свих сталежа, те изгледа да се слободно кретао кроз све слојеве друштва, подучавајући и шогуна и цара, а био је пријатељ и учитељ уметника мачевања Мијамото Мусашија. Изгледа да није подлегао својој слави, а пред смрт је рекао ученицима: „Сахраните моје тело на планини иза храма, прекријте га прљавштином и отиђите кући. Не читајте сутре, не одржавајте никакве церемоније. Не примајте поклоне ни од монаха ни од световних људи. Пустите монахе да носе своју одору, једу своје оброке и обављају своје свакодневне обавезе.“ У последњем тренутку, написао је идеограм за сан (јуме, 夢), одложио четкицу и мирно умро.

Иако је рођен у самурајској породици клана Миура у јеку друштвених раздора који су трајали већ 150 година, Такуан је приступио манастиру у 10. години да би учио ђодо школу будизма, у 14. години је прешао на практиковање ринзаи школе зена и, са невероватних 35 година, постао старешина храма Даитокуђи, главног зен храма у Кјоту.

Верује се да је до самога краја Такуан ходао својим независним, бескомпромисним и помало горким путем. Његова снага очигледна је 
у његовим сликама и калиграфијама. Такуанов живот и стремљења можда се могу описати његовим речима: „Ако следите данашњи свет, окренућете леђа Путу; ако не желите да скренете са Пута, не следите свет.“ (Сохо, 2004: 9)

Прича се да је Такуан тежио да духом зена обогати сваки сегмент живота који га је занимао, као што су калиграфија, поезија, баштованство, и уметност уопште. Ово је чинио и са уметношћу мачевања. Пошто је живео у последњим данима великог грађанског рата који је кулминирао у бици Секигахара (1600), Такуан је био упознат не само са мирноћом и узвишеношћу уметника и мајстора чаја, већ и са сукобом - победе и пораза - ратника у целини. Његови каснији ученици биле су изузетно различите личности као што су Ишида Мицунари, моћни генерал који је подржао Тојотоми Хидејошија; Курода Нагамаса, феудални господар који је примио хришћанство; и посебно његов пријатељ Јагју Муненори, оснивач Јагју Шинкаге школе мачевања и учитељ три генерације шогуна. Међутим, овим људима Такуан се није ништа више обраћао него другима.

Такуанова три најпознатија есеја упућена су самурајској класи, и сва три теже уједињењу духа зена са духом мача. Савети које у њима износи су мешавина практичног, техничког и философског аспекта мачевалаштва. Уопштено се може рећи да се Мисиеериозни

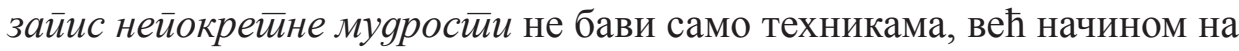
који се ја (сопство) може довести у везу са Изворним собом и како појединац може постати целина. С друге стране, „Анали мача Таије“ (Таиаки, 太阿記) више се баве питањем философског аспекта односа између природе (бића) и свега што је окружује. Есеј ,Чист звук драгуља“ (Реироиу) бави се фундаменталном природом људског бића и тиме како мачевалац, gauмjo или било ко други може да спозна разлику између исправног и себичног и на који начин се може разумети основно питање сазнања када и како треба умрети. Ипак, сва три есеја управљени су ка индивидуалној спознаји властитог унутрашњег знања, те стога представљају уметност живљења.

Иако се зен чврсто утемељио крајем XII века, мачевалаштво и медитативни зен тек су са Такуаном достигли истинско сједињење. Такуанова размишљања о мачевалаштву била су од изузетног значаја за развој мачевалаштва у Јапану. Чврсто успостављајући уједињење зена и мача, Такуанова размишљања и дела утицала су на бројне 
Соња С. Вишњић Жижовић

мајсторе тог времена, између осталог и на Мијамото Мусашија да напише своју Кюиіуу иеети ирстиенова.

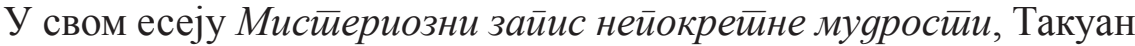
каже:

[...] Ако га нигде не усресредиш (тј. зауставиш), твој ум ће се кретати у свим деловима тела и ширити се у својој целости. На овај начин, када уђе у руку схватиће функцију руке. Када уђе у стопало, схватиће функцију стопала. Када уђе у око, схватиће функцију ока. Ако треба да се одлучиш за једно место и ту усресредиш ум, заробићеш га тим местом и изгубиће функцију. Ако размишљате заробиће вас мисли. Због тога, оставите по страни мисли и разликовања, избаците ум из целог тела, не заустављајте га тамо-вамо, а када дође до одрећеног дела тела схватиће његову функцију и делаће без погрешке.

[...] Када не размишљате о томе где да поставите свој ум, он се слободно креће целим телом. Зар не постављајући ум ни на једно место, нисте у стању да га у потпуности употребите и пролагодите своје покрете кретањима противника? Ако се ум креће целим телом, када рука треба да делује, користите ум који је у руци. Када треба нога да реагује, користите ум који је у нози. Али, ако се одлучите за једно место на које ћете поставити свој ум, нећете моћи, колико год да покушавате, да га померите са тог места. Заправо, ваш ум ће бити неупотребљив.

[...] Циљ ваше вежбе је достићи ум који се никада не зауставља. Не постављајте га нигде и биће свугде. Чак и да крећете ум ван тела, ако га пошаљете у једном правцу, неће га бити у осталих девет. Ако га не ограничавате на један правац, биће у свих десет.“ (Сохо 2004: 27-28)

Такуан не-ум поистовећује са исправним умом у којем нема мисли и који се не задржава ни на једној ствари. Због тога је то своје схватање ислустровао старом песмом спеваном у духу зена: Мислити: „Не желим да мислим“ / такође је у нечијим мислима. / Једноставно не размишљај о неразмишљању. (Сохо 2004: 31)

Такуан ће чак једно своје дело назвати тако да у наслову садржи реч „мач“. У питању је дело Анали мача Taије. Иако је реч о чувеном, древном кинеском мачу, опточеном драгуљима и од чврстог метала и прекаљеног челика, за Такуана је овај мач симбол непобедивости, тачније исправног стања ума. Тако он каже: „Сви људи поседују овај 
оштри мач Таије, и у сваком човеку је он савршено уређен и довршен... Он [мач Таије] је ствар ума““ (Сохо 2004: 86). Он је човеково изворно лице (прастара природа ума, неупрљана човековим намерама и акцијама. „Небо га не може прекрити, Земља га не може носити. Ватра га не може спржити, нити га вода може потопити. Ништа под небеским сводом га не може нарушити.“ (Ибиg)

Такуан дело завршава речима да мајстор (исправног ума) поседује невероватну брзину, да никада не компромитује врх свога мача, али и да се права вештина не достиже звањима и (кишким) знањем, да се не може пренети речима или упутствима, нити учењем неке доктрине, већ да је у питању учење које се заснива на посвећености и самостварењу. Такође, ако је мачевалац прекали своју вештину, спознао себе и достигао не-ум (када дела из празнине) „све под небом контролисаће тим једним уздигнутим мачем“ (Сохо 2004: 93).

Управо због оваквих ставова и учења Такуан Сохо се сматра једним од најзаслужнијих за сједињење духа зена са духом мача. У ратним временима философија зена је помагала ратнику да се суочи са смрћу, али и да цени живот који је спремно требало да положи за праведну ствар, а у мирнодопском времену мач и даље остаје оруђе којим човек треба да одстрани властито незнање и его, чинећи га модерним ратником који треба да добије ону највећу битку од свих - битку са самим собом.

\section{5. ЗАКЉУЧАК}

Кенgо или „пут мача“, одувек је у Јапану био синоним за племство. Од оснивања ратничке класе у VIII веку, војна вештина постала је један од највиших облика учења, у почетку надахнута шинтоизмом, а касније и зен огранком будизма. Бројне школе кенgа из периода Муромаћи (XIV-XVI век) одржале су се и до данас. Надахнут и кинеским борилачким вештинама, јапански кенgо се повезивао са храмовима, али и замковима. Наиме, сваки gаимјо је новчано потпомагао неку школу кенga, ангажујући учитеље мачевања који су тој вештини могли да подуче и њихове синове. Међутим, јапански пут мача не означава само борбену технику, већ и живљење према самурајском кодексу части. Тако је јапански кенgо или „пут мача“ морално учење самураја поткрепљено конфуцијанизмом, заједно са матерњом шинто 
Соња С. Вишњић Жижовић

религијом. Ипак, духовној димензији пута мача највише је допринео зен будизам.

Зен будизам своје изворе има у индијској и кинеској мисли. На овај начин је као философски правац зен идиосинкразија три различите културе. Он је типична јапанска творевина која осликава индијски мистицизам, таоистичку љубав према природи, али и спонтаност и чврсти прагматизам конфучијанске мисли. Међутим, у својој суштини, зен је чисто будистички правац пошто је његов крајњи циљ постизање будаства, пробуђености, просветљења, у зену познатом као сайори. Према становишту зена, пробуђеност Буде и његово учење доступни су свима. Они се постижу кроз лично искуство па стога зен превазилази све категорије интелекта и мишљења и није заинтересован за апстракцију или концептуализацију. Пошто афирмише ослобођеност од свих устаљених веровања, зен нема никакву философску догму. Више од било које школе источњачког мистицизма, зен је убеђен да речи никада не могу да пренесу Истину. Међутим, у зену је могуће преношење искуства са учитеља на ученика. Техника 'директног указивања' садржи посебан укус зена. Она је типична за јапански ум који је више интуитиван него интелектуалан и који чињенице износи без много коментара. Због тога зен мајстори нису много говорили, презирали су теоретисање и спекулације, па су своје учење базирали на зен коанима ${ }^{4}$ који за циљ имају да зауставе процес мисли и допринесу спремности ученика за изненадно мистично или духовно искуство.

Савршенство зена огледа се и у вођењу спонтаног и природног свакодневног живота. Начела као што су спонтаност и природност, зен је сигурно преузео од таоизма. Због идеје да се просветљење испољава у свакодневном животу, зен је извршио изузетно јак утицај на све видове традиционалног јапанског начина живота. Он није утицао само на сликарство, калиграфију, уређење башта, већ и на чајну церемонију, драмску уметност, али и на ратничку класу и њихове борилачке вештине. Свака од ових уметности у Јапану позната је као 'пут' $(g o)^{5}$ - пут до просвећења. Кроз све аутентично јапанске умет-

4 Зен коан - пример који зен мајстор даје свом ученику, уобличен тако да отклони интелектуална ограничења и изазове блесак изненадне интуиције за постизање саторија (просветљења). Коани се често излажу у виду нерешивих проблема, бесмислених за интелект, а суштински елемент је најчешће неки нелогичан или апсурдан поступак или реч.

5 Пут (јап. go); на пример: кјуgo, пут стреле или стреличарство; кенgo, пут 
ности надахнуте зеном, уметников ум треба да постигне повезаност са крајњом стварношћу, чиме његова уметност постаје израз спонтаности, једноставности и свесности. Право мајсторство се не постиже само усавршавањем технике, већ се јавља када техника постане 'неуметничка уметност' која израња из несвесног.

Пошто су основна обележја будизма саосећање и љубав, може изгледати невероватно да је зен утицао на ратничку класу у Јапану. Међутим, пошто је зен религија која подучава да идемо напред и да се никада не осврћемо када се једном определимо за смер, равнодушан је према животу и смрти, па је јапанским самурајима пружио пасивну подршку у моралном и философском смислу. Према речима Дејана Разића, пошто је зен религија воље, самурајима је одговарао више морално него философски. Ратнички ум, који је једноставан и није склон философирању, нашао је одговарајући дух у интуитивном зену. Борбеном духу ратника одговарао је и аскетски карактер зена јер је зенистичка дисциплина једноставна, непосредна и заснива се на самоодрицању и ослањању на самога себе. Ратник је увек морао да буде усмерен ка једном: да се бори, да не гледа уназад и да увек буде спреман на смрт. Јер, према речима Даисецу Сузукија, „највеће тајне мачевалаштва леже у томе како се ослободити мисли о смрти“ (Сузуки, 1992: 22). Он даље објашњава како мисао о смрти с једне стране чини да се „наше размишљање пружи изван граница овог коначног живота и, с друге стране, толико нас притеже да почињемо озбиљно да прилазимо свакодневном животу“ (uбиg 1992: 23). Исто је и са највећим симболом самураја, мачем, који, представљајући силу интуитивне и нагонске непосредности, служи не само за онеспособљавање непријатеља, већ и за уништење сопствених слабости. Тако је мачевалаштво, налазећи надахнуће у зену, постало пут ка моралном и духовном усавршавању самураја.

Према учењу великих јапанских мајстора мача, савршени мачевалац избегава свађу или борбу. Најбоље је бити победник без борбе. Као ратник, самурај мора да усаврши уметност мачевања. Ипак, суштина је у томе да ову уметност ратник треба да искористи као средство за напредовање и проучавање Пута (таоа). Уколико се оваква уметност правилно користи, може да допринесе оплемењивању ума и духа.

мача или мачевалаштво; бушияо, пут ратника; ћаgо, пут чаја и сл. 
Соња С. Вишњић Жижовић

Сузуки такође истиче како се једна од великих предности коју мач има у односу на читање књига, састоји у томе да се, чим се направи погрешан корак, противнику даје шанса да те победи. „Ту непрестано мораш да будеш на опрезу. Иако приправност не значи врхунац мачевалаштва, она нас одржава верним себи: то јест, она нам не допушта да се упуштамо у бескорисна размишљања.." (Сузуки 1992: 84) Ово је практична примена неких учења школа мачевања о 'делању не-делањем’ па је савршена победа она која се оствари без намере да се победи.

Учење зена о превазилажењу дуалности и сажимању субјекта и објекта омогућило је многим мајсторима да схвате да циљ познавања технике јесте да мачевалац, на крају, схвати да се она мора превазићи. Зен ставља нагласак на једноставност и самоконтролу, на пуну свесност у сваком тренутку и на смиреност када се треба суочити са смрћу. Те идеје су се савршено уклапале у самурајски начин живота, у коме је дуел увек био могућ, а живот и смрт делио је само један ударац мача. Самурајима је опуштање кроз медитацију омогућавало да умире свој узнемирени ум, да опазе коначни склад у привидном нескладу и да постигну јединство интуиције и акције. Зато се, према речима зен учитеља Тајсен Дешимаруа (泰仙弟子丸), зен заиста може сматрати „религијом самураја“ (Дешимару, 1999: 10), а мач, додали бисмо, њиховом душом.

\section{ЛИТЕРАТУРА}

Baker S. (1998). Japanese Art. New York: Thames and Hudson.

Čogjam, T. (2003). Meditacija u akciji. Niš: Prosveta.

Devide, V. (1988). Japan - prošlost i budućnost u sadašnjosti. Zagreb: Znanje. JAPAN, Profile of a Nation, Kodansha International, Tokyo-New York-London, 1994.

Kapra, F. (1989). Tao Fizike. Beograd: Opus.

Ogasawara, N. (1970). Japanese swords. Japan: Hoikusha.

Razić, D. (1985). Zen. Gornji Milanovac: Dečje novine.

Suzuki, D. (1992). Zen i samuraji. Novi Sad: Svetovi.

Suzuki, D. (2005). Zen i japanska kultura. Beograd: Geopoetika.

Suzuki, D. i From, E. (1973). Zen budizam i psihoanaliza, Beograd: Nolit. 
Tajsen, D. (1999). Beograd: Babun.

Vasilijev L. (1987). Istorija religija Istoka. Beograd: Novo delo.

Муненори J. (2006). Живойоgавни мач. Београд: Либер.

Мусаши М. (2006). Књиїа иеей иррсиенова. Београд: Либер.

Нитобе, И. (1986). Бушияо - Коgекс самураја. Београд: Борислав Станић и Михаило Станић, Београд.

Cохо, Т. (2004). Ослобођено срие. Београд: Либер.

Стори, Р. (1987). Живой самураја. Београд: Југословенска ревија.

Харц, П. (2002). Шинйо - светиске релиїије. Београд: Чигоја штампа.

\title{
Sonja S. Višnjić Žižović
}

\section{INFLUENCE OF ZEN BUDDHISM ON JAPANESE SWORDSMANSHIP}

\begin{abstract}
Summary
The art of swordsmanship in Japan has been developing since 12th century (Kamakura period) when the ruling class of Japan was preoccupied by mastering it. Also, in that period, Zen Buddhism for the first time came to Japan as independent school of thought. A vast number of Japanese warriors gathered around Zen masters because their simple and direct method of teaching was suited to them. Actually, because the life of warriors was in constant danger and sword was the only weapon that could decide their fate, the art of sword in Japan has been developed to the extraordinary extent. In that, Zen Buddhism contributed to a great extent. Many Zen teachers counseled their warriors-students not only regarding sword techniques, but also the right state of mind - above all, the warrior's attitude towards death.

Although there were numerous famous Japanese swordsmen who tried to handle the sword by principles of Zen, for the purpose of this paper and being limited by space, we decided to analyze and compare the work of three masters Miyamoto Musashi, Yagyu Munenori and Takuan Soho. Those three are considered to be the most meritorious for joining the spirit of Zen with the spirit of the Sword. By analyzing their works we hope to point out that it was imbued with Zen whose basic principles, such as emptiness, no-mind, simplicity, naturalness, have been influenced numerous Japanese arts, primarily swordsmanship.
\end{abstract}

Key words: Japan, swordsmanship, Zen Buddhism, emptiness, no-mind, Musashi, Munenori, Soho. 